\title{
Sprawozdanie z IV Ogólnopolskiego Kongresu Politologii (panele rosyjskojęzyczne)
}

$\mathrm{P}$ odczas IV Ogólnopolskiego Kongresu Politologii, który miał miejsce w Lublinie w dniach 18-20 września 2018 roku ${ }^{1}$, odbyły się trzy rosyjskojęzyczne panele, z których dwa zorganizowało Centrum Europy Wschodniej UMCS: »Консолидация государств Новой Восточной Европы в аспекте новых вызовов и угроз национальной безопасности« (moderator - prof. dr hab. Walenty Baluk, Dyrektor Centrum Europy Wschodniej) oraz »Культурная безопасность государств Восточной Европы« (moderator - dr Nadia Gergało-Dąbek). Wybór rosyjskojęzycznej opcji językowej był podyktowany kilkoma aspektami, m.in. profilem badań Centrum Europy Wschodniej, możliwością włączenia do programu badaczy z krajów byłego Związku Radzieckiego, w tym z Rosji. Kongres Politologii, którego tematem przewodnim było „Państwo w czasach zmiany”, był doskonałą okazją, by dotychczasowa współpraca Centrum Europy Wschodniej z ośrodkami naukowo-badawczymi nabrała wymiaru praktycznego.

W zorganizowanych przez CEW UMCS w ramach IV Kongresu Politologii panelach wzięli udział naukowcy z Ukrainy, Białorusi, Izraela, Rosji i Gruzji. Panel »Консолидация государств Новой Восточной Европы в аспекте новых вызовов и угроз национальной безопасности („Konsolidacja państw Nowej Europy Wschodniej przez pryzmat nowych wyzwań i zagrożeń dla bezpieczeństwa narodowego") dotyczył m.in. problemów na drodze demokratycznego tranzytu i konsolidacji demokracji w przestrzeni postsowieckiej, nowych wyzwań i zagrożenia dla bezpieczeństwa narodowego krajów Nowej Europy Wschodniej, które odgrywają decydującą rolę w procesie konsolidacji państwa. W ramach tego panelu referat „Democratization Through Convergence: the Role of External Factors in Political Transition in Eastern Europe" zaprezentowała prof. Hałyna Zeleńko z Instytutu Badań Politycznych i Etnonarodo-

1 Zob. sprawozdanie ogólne z Kongresu: Ł. Jędrzejski, Sprawozdanie z IV Ogólnopolskiego Kongresu Politologii w Lublinie, „Wschód Europy” 2018, vol. 4, nr 1, s. 155-157. 
wych im. I.F. Kurasa Narodowej Akademii Nauk w Kijowie, która dokonała analizy czynników zewnętrznych i ich roli w transformacji politycznej w Europie Wschodniej. Prof. dr hab. Walenty Baluk z Centrum Europy Wschodniej UMCS w swoim wystąpieniu przestawił analizę tranzytu demokratycznego i konsolidacji państw Partnerstwa Wschodniego. Dr hab. Ołena Dobrżańska z Kijowskiego Narodowego Uniwersytetu im. T. Szewczenki skupiła się na zagadnieniu europejskiej tożsamości jako podstawie konsolidacji państw Nowej Europy Wschodniej. Z kolei prelegent z Gruzji, prof. Alexandre Kukhianidze (Uniwersytet im. Ivane Javakhishvili, Tbilisi), szczegółowo omówił zagrożenia dla bezpieczeństwa narodowego i konsolidacji Gruzji w okresie postsowieckim. Referat „Zmiana polityki bezpieczeństwa narodowego Ukrainy po $2014 \mathrm{r}$. i miejsce państwa w Nowej Europie Wschodniej” zaprezentowała dr Kateryna Grąbczewska z UMCS w Lublinie.

W drugim panelu CEW - »Культурная безопасность государств Восточной Европы « („Bezpieczeństwo kulturowe państw Europy Wschodniej”) - dr Nadia Gergało-Dąbek zwróciła uwagę na szczególną rolę bezpieczeństwa kulturowego w Europie Wschodniej w kontekście hybrydowych form agresji. Kraje Europy Wschodniej, które stosunkowo niedawno odzyskały niepodległość i których proces kształtowania się tożsamości narodowo-kulturowej nie został jeszcze zakończony, stanęły w obliczu dodatkowych zagrożeń i wyzwań w zakresie bezpieczeństwa kulturowego. Wraz z globalizacją, migracjami i innymi cywilizacyjnymi wyzwaniami współczesnego świata muszą one również stawić czoła kulturalnej dominacji Federacji Rosyjskiej. Kwestię bezpieczeństwa kulturowego w Europie Wschodniej analizował w swoim wystąpieniu również prof. Wasyl Klymonczuk z Podkarpackiego Uniwersytetu Narodowego im. Wasyla Stefanyka. Z kolei prof. Zachar Szybieka z Centrum Badań nad Diasporą Żydowską Uniwersytetu w Tel Awiwie przedmiotem swojej analizy uczynił elity białoruskie w referacie „Wielokulturowość czy schizofrenia kulturowa elit białoruskich?”. Prof. Jurij Makar we współautorstwie z prof. Natalią Rotar z Czerniowieckiego Narodowego Uniwersytetu im. Jurija Fed'kowycza zaprezentował analizę transformacji kultury elektoralnej w Ukrainie od praktyk autorytarnych do modelu demokratycznego. Kolejny prelegent - prof. Serhij Danyłenko z Narodowego Uniwersytetu im. T. Szewczenki w Kijowie - przeanalizował rolę i wpływ czynnika medialnego w polsko-ukraińskim dyskursie historycznym. Przedmiotem swojego zainteresowania dr Oksana Wojtiuk z Uniwersytetu w Białymstoku uczyniła z kolei stan świadomości narodowej mieszkańców Donbasu oraz porównała postawy życiowe, świadomość i radzenie sobie z wymuszoną migracją przesiedleńców z terenów okupowanych i Tatarów Krymskich, którzy musieli opuścić anektowany przez Rosję Krym.

Trzeci panel rosyjskojęzyczny pt. »Суверенитет versus конкурентоспособность: есть ли выбор у государства?« („Suwerenność a konkurencyjność: czy państwo ma wybór?") został zainicjowany przez badaczy z Rosji - moderatorką panelu była prof. Aleksandra Głuchowa z Uniwersytetu Państwowego w Woroneżu. W swoim jednobrzmiącym z tytułem panelu referacie badaczka skupiła uwagę na takich zagadnieniach, jak: kwestia suwerenności państwa w globalnym świecie, rola i znaczenia suwerenności, 
zagrożenia dla bezpieczeństwa i czynniki zdolności konkurencyjnych. Jak zauważyła prof. A. Głuchowa, w obliczu procesów globalizacyjnych państwo traci status jedynego podmiotu politycznego, a gospodarka przekracza granice państw i jest coraz bardziej zorientowana na skalę globalną. Prelegentka odnotowała fakt, że powstaje nowa rzeczywistość polityczna, której zrozumienie staje się głównym zadaniem nauk społecznych. W obliczu tego nowego zjawiska pojawia się problem harmonizacji interesów gospodarczych skoncentrowanych na rynku globalnym oraz ograniczeń politycznych i prawnych narzuconych przez państwo narodowe. Dr Ilja Pomigujew z Uniwersytetu Finansowego przy Rządzie Federacji Rosyjskiej omówił wpływ zewnętrznych weto-graczy na ustawodawstwo jako czynnik rozwoju państw narodowych. Następny prelegent - prof. dr hab. Jerzy Garbiński z Uniwersytetu Marii Curie-Skłodowskiej w Lublinie - w swoim referacie przeanalizował stan rzeczywisty i perspektywy suwerenności Republiki Białoruskiej w warunkach pogłębienia integracji białorusko-rosyjskiej. Z kolei mgr Alexandra Viktoria Martines w swoim wystąpieniu „Trójkolor przeciwko czerwonemu sztandarowi. Konflikt dwóch paradygmatów" omówiła konflikt dwóch sposobów postrzegania rzeczywistości we współczesnej Rosji.

Uczestnicy zorganizowanych przez CEW paneli odnotowywali, że od czasu aneksji Krymu i wojny hybrydowej Rosji przeciwko Ukrainie nastąpił faktyczny zanik współpracy naukowej i spotkań badaczy z Ukrainy i Rosji. Z uwagi na zaprzestanie wyjazdów naukowców z Ukrainy do Rosji z różnych powodów (światopoglądowych, obawą o bezpieczeństwo i in.) i odwrotnie zniknęła możliwość zderzenia poglądów, przemyśleń, wyników swoich analiz i badań, m.in. dotyczących obecnej sytuacji, z drugą stroną. Taką możliwość dają natomiast przedsięwzięcia odbywające się w krajach trzecich. W tym kontekście zorganizowane przez Centrum Europy Wschodniej w ramach IV Kongresu Politologii panele stworzyły platformę do wymiany doświadczeń, dzielenia się wynikami badań naukowych i skonfrontowania poglądów. 